\title{
Modeling the Factors that Affect the Implementation of Knowledge Networks
}

\author{
Ali Rezaeian \\ Professor, a_rezaeian@sbu.ac.ir \\ Rouhollah Bagheri \\ PhD Candidate, r_bagheri@sbu.ac.ir \\ Shahid Beheshti University, Daneshju Blvd, Evin Square, Tehran 1983963113, Iran
}

\begin{abstract}
$\mathrm{K}$ nowledge is increasingly recognized by organizations as an important source of lasting competitive advantage. Knowledge networks are a mechanism used to support knowledge sharing and creation. Variables important for implementing a knowledge network are described by numerous researchers, but few studies have been undertaken to understand the interaction between these variables and to develop a model of the hierarchy of variables in the knowledge network. This paper identifies a set of variables necessary for the operation of a knowledge network and then analyzes and ranks them using interpretive structural modeling (ISM).

The study identified seven key factors affecting the implementation of knowledge networks and revealed contextual relationships among these variables. Some

variables, the drivers, are little impacted by other factors, while others, the dependent variables, have limited potential to exert an influence on other factors and are furthermore determined by the drivers. The former includes such factors as an organization's environmental factors, managerial processes, IT infrastructure, while the latter encapsulates the resultant effects such as knowledge, culture, organizational structures, and communication processes.

The use of ISM in the development of a hierarchy and the categorization of variables affecting the implementation of knowledge networks provides one with a better understanding of causal relationships between said variables, thus allowing one to identify which elements to concentrate upon and how trade-offs between variables should be managed.
\end{abstract}

Keywords: knowledge network; knowledge management; interpretive structural modelling (ISM); driver variables; dependent variables.

Article type: research paper

Citation: Rezaeian A., Bagheri R. (2018) Modeling the Factors that Affect the Implementation of Knowledge Networks. Foresight and STI Governance, vol. 12, no 1, pp. 56-67. DOI: 10.17323/2500-2597.2018.1.56.67 
I a "knowledge society" in which individual and organizational knowledge can make a difference in gaining a competitive advantage, knowledge management is essential for all companies [Enkel et al., 2007]. The World Bank, for example, demonstrates how a network structure could facilitate internal innovation as well as what is required to follow the networking strategy successfully [Wood, Hamel, 2002; Enkel et al., 2007]. Knowledge networks focus on the members' knowledge [Back et al., 2005]. They are social networks that can be defined as a specific set of linkages among a defined set of actors, that is, the characteristics of these networks as a whole may be used to interpret the social behavior of the actors involved [Alba, 1982; Lincoln, 1982; Mitchell, 1969; Tichy et al., 1979]. The term 'network' focuses on the social relationship between the members [Badaracco, 1991]. The word 'knowledge network' is, therefore, used to signify many people, their resources, and the relationships between them as well as those who are assembled to accumulate and use this knowledge in order to gain a competitive advantage, primarily utilizing the processes of knowledge creation and sharing [Hildreth, Kimble, 2004; Hung, 2006]. Networks indicate not only the relationship among members, but also the accessibility and exchange of knowledge in networks. Knowledge networks can be regarded as instruments for knowledge production, sharing, and management [Jayrama, Ayvari, 2005]. The barriers for communication, which are caused by the hierarchical and functional view of the main organization, can be overcome through networking, the facilitation of connections between knowledge agents. In studies of organizational development and learning, the "network forms" of the organization have been defined as a source of value for the firm [Ring, 1997; Kogut, 2000]. Organizations may be expected to generate new forms of collaboration, in which network partnerships are based on maximizing resource utilization, subject to the equitable distribution of returns, rather than on individual firms maximizing their profits [Miles et al., 1998].

The implementation of a knowledge network allows for the reduction of organizational expenditures through reducing reworks [Parker et al., 2001]. Moreover, it plays an important role in developing and increasing the competitive advantage of the organizations [Argote, 2012] and results in an increase in organizational learning through the conversion of personal knowledge into organizational knowledge, and thus, an increase in the success of research and development projects [Raidén et al., 2004].

Although knowledge networks can enhance the management of knowledge within an organization, little attention has been paid to the relationships between the variables of knowledge networks. Ranking the factors that affect knowledge networks will be very helpful to focus on the most important variables and to raise efficiency in knowledge management.

This paper contributes to filling in research gaps. It identifies variables for the implementation of a knowledge network and discovers contextual relationships among the distinguished variables. The analysis is based on a literature review and surveys from industry experts and respondents in academia. Using these sources, the ISM technique is applied to develop a structural model. The variables are classified via a MICMAC analysis, i.e., accomplishing the Matrice Impacts Croise's Multiplication Applique'e a' un Classement (MICMAC) [Ravi, Shankar, 2005]. In applying these data, managers can prepare an action plan to set up knowledge network.

\section{Literature Review}

\section{Interpretive Structural Modeling (ISM)}

Many researchers have used ISM methodology in order to impose order and direction upon the complexity of relationships among the variables of a system. The application of ISM typically forces managers to reassess perceived priorities and improves their understanding of the linkages among key concerns. The ISM methodology's mathematical foundations can be observed in reference works [Harary et al., 1956]. Its fundamental idea is to apply the experts' practical experience and knowledge to decompose a complicated system into several subsystems and construct a multilevel structural model. ISM was first proposed by J. Warfield in 1974 to analyze complex socioeconomic systems [Warfield, 1974]. Subsequently, ISM has been employed for policy analysis [Sage, 1977] and, recently, for the study of management [Ravi, Shankar, 2005; Diabat, Govidan, 2011; Jharkharia, Shankar, 2005; Luthra et al., 2011; Mandal, Deshmukh, 1994; Mudgal et al., 2009; Mudgal et al., 2010; Sarkis et al., 2007; Sushil, 2005]. Jharkharia and Shankar [Jharkharia, Shankar, 2005] applied ISM to understand the barriers in the IT enablement of supply chains. Mandal and Deshmukh [Mandal, Deshmukh, 1994] used the ISM methodology to analyze some of the important vendor selection criteria and have demonstrated the interrelationship between criteria and their levels. These criteria have also been categorized according to their driver power and dependence. Sharma and Singh [Sharma, Singh, 2013] applied the ISM technique to develop a hierarchy of identified individual knowledge sharing barriers (IKSBs) according to their driving power. Singh et al. applied ISM to modeling knowledge management in engineering industries, in this research, the important elements (also referred to as variables) for knowledge management implemented in engineering industries have been analyzed to obtain an interpretive structuring model, which shows the interrelationships of the variables and their levels; these variables also have been categorized according to their driving power and dependencies [Singh et al., 2003].

Patil et al. [Patil et al., 2016] have applied the ISM technique in their research to determine a roadmap of knowledge management (KM) implementation and to categorize KM principles based on their driving power for manufacturing industries. In this research, an ISM model was developed for the hierarchy of the identified KM. The ISM model results a hypothetical hierarchy, which needs proper quantitative analysis to evaluate the percentage effectiveness in the hierarchy.

Taghizadeh and Shokri [Taghizadeh, Shokri, 2015] used the ISM technique to identify the internal relationships among the dimensions of knowledge management from the viewpoint of social capital.

The main areas of ISM application are summarized in Table 1. 
Table 1. Examples of Previous Research in ISM

\begin{tabular}{|l|l|}
\hline \multicolumn{1}{|c|}{ Researcher(s) } & \multicolumn{1}{c|}{ Area in which ISM has been applied } \\
\hline$[$ Patil et al., 2016] & Knowledge management implementation in Indian automobile ancillary industries \\
\hline$[$ Taghizadeh, Shokri, 2015] & Knowledge management from the viewpoint of social capital \\
\hline$[$ Sharma, Singh, 2013] & Knowledge sharing barriers: an integrated approach to ISM and AHP \\
\hline$[$ Kanungo, 2009] & Evaluating IT effectiveness \\
\hline$[$ Kant, Singh, 2008] & Knowledge management implementation - Modeling the barriers \\
\hline$[$ Singh et al., 2003] & Knowledge management in engineering industries \\
\hline$[$ Sharma, Gupta, 1995] & The objectives of waste management in India \\
\hline$[$ Mandal, Deshmukh, 1994] & Vendor selection criteria \\
\hline$[$ Saxena, Vrat, 1992 $]$ & Hierarchy and classification of program plan elements \\
\hline$[$ Hawthorne, Sage, 1975$]$ & Higher education program planning \\
\hline Source: composed by the authors. &
\end{tabular}

\section{Knowledge Networks}

The term 'network' can be interpreted as those of groups, individuals, or businesses, as well as within cooperatives of organizations [Gupta, Polonsky, 2014]. In all cases, the network construct requires that description and analysis not focus merely on a division of the relationships which exist between the network associates and network relationships, but also comprehends the network in its entirety [Alkhuraiji et al., 2016]. One could credit the works of Fayol with the origin of research on network structures [Fayol, 1917; Seufert et al., 1999]. Today, hardly any organization remains unaffected by the evolution of network-like relationships within and between firms [Alkhuraiji et al., 2014].

The term 'knowledge networking' [Schneckenberg, 2015] is used to signify many knowledge workers (people), and the resources and relationships they possess, who are assembled to accumulate and use knowledge primarily through the processes of knowledge creation and knowledge transfer for the purpose of creating value [Plum, Hassink, 2011]. Knowledge creation and transfer can occur at different real (e.g., in the office, with clients), virtual (e.g., distributed team rooms) or mental (e.g., common values, ideas, ideals) places [Seufert et al., 1999]. The major function of knowledge networks is to acquire and share inter- and intra-organizational knowledge and make it accessible thus raising the efficiency of knowledge management [Swan et al., 1999; Lewis-Pryde, Evans, 2016; Tavallaee et al., 2012].

According to [Easton, 1992], one approach to networks is to consider them series of communication units. The process of producing knowledge has been attached to a complicated network of activities, institutes, and diffusion factors [Klimasauskiene, 2003]. Network building can help organizations to find the necessary knowledge and use it to introduce successful innovations [Lewis-Pryde, Evans, 2016; Benson et al., 2012].

Studies performed in organizations show that one of the major challenges facing knowledge management systems is the individuals' low inclination to document and share knowledge [Yang, Chen, 2009], hence, organizations try to increase knowledge-sharing through the launching of knowledge networks.

The above literature review and discussion with experts in the field of knowledge management allowed for the identification of seven variables that need to be addressed by those organizations that are planning to implement a knowledge network or are in the process of its implementation (Table 2).

\section{Variables}

Organizational Environmental Factors: Organizational theorists emphasize that organizations must adapt to their environment if they are to remain viable [Duncan, 1972]. Environmental factors can be both internal and external to an organization. Rice [Rice, 1963] defined the internal environment as that which includes the interpersonal relations of members and their interactions with each other, while the external environment includes other individuals, groups, and institutions. A more comprehensive distinction between internal and external environments is proposed by Özsomer et al. [Özsomer et al., 1997]. According to them, the internal environment consists of those relevant physical and social factors within the boundaries of the organization, including its value system, mission and objectives, and internal relationships. The external environment consists of those relevant factors outside the boundaries of the organization such as competitors and the competitive situation, economic, and technological factors. Altogether, these factors play an important role in the formation and development of knowledge relations and the sharing of best practices among the personnel of an organization [Zhou et al., 2009]. Thus, the organizational environment was chosen from the literature as a factor influencing the successful implementation of knowledge networks.

Organizational Structures: Organizational structure is a system that consists of explicit and implicit institutional rules and policies designed to outline how various work roles and responsibilities are delegated, controlled, and coordinated [Özsomer et al., 1997]. Based on [Miller, Dröge, 1986] organizational structures are defined as capturing the centralization of authority, formalization, complexity, and integration. Organizational structure also determines how information flows from level to level within a company. This factor formalizes the activities within knowledge networks. The organizational structure should be 
Table 2. List of variables from literature review, that affect knowledge network

\begin{tabular}{|c|c|c|}
\hline No. & Variable & Reference \\
\hline 1 & $\begin{array}{l}\text { Organizational environmental } \\
\text { factors }\end{array}$ & [Back et al., 2005; Cross, Baird, 2000; Jennex, Olfman, 2001, 2004] \\
\hline 2 & Knowledge & [Back et al., 2005; Leonard, 2006; Miles, Snow, 1986; Alkhuraiji et al., 2014; Singh et al., 2003] \\
\hline 3 & Culture & $\begin{array}{l}\text { [Alavi, Leidner, 1999; Back et al., 2005; Barna, 2003; Davenport et al., 1998; Jennex, Olfman, } \\
\text { 2001; Sage, Rouse, 1999; Yu et al., 2004; Zahra et al., 2007; Alkhuraiji et al., 2016; Alkhuraiji } \\
\text { et al., 2014; Holtshouse et al., 2013; Singh et al., 2003] }\end{array}$ \\
\hline 4 & IT Infrastructures & $\begin{array}{l}\text { [Alavi, Leidner, 1999; Barna, 2003; Cross, Baird, 2000; Davenport et al., 1998; Ginsberg, } \\
\text { Kambil, 1999; Jennex, Olfman, 2001; Sage, Rouse, 1999; Wejnert, 2002; Yu et al., 2004; Zahra } \\
\text { et al., 2007; Holtshouse et al., 2013; Matković, Tumbas, 2010; Singh et al., 2003] }\end{array}$ \\
\hline 5 & Managerial Processes & [Askarany et al., 2007; Cross, Baird, 2000; Joshi, 2006; Lin, 2008; Palmié, 2012] \\
\hline 6 & Organizational Structures & [Back et al., 2005; Kim et al., 2006; Nonaka et al., 1998; von Krogh et al., 2001] \\
\hline 7 & Communication Processes & [Back et al., 2005; Figallo, Rhine, 2002; Johnson, 2006] \\
\hline
\end{tabular}

adjusted so as to enable the production, storage, circulation, and diffusion of knowledge in different parts of knowledge networks. Organizations with flexible processes and organizational structures tend to be better at output and managing knowledge than more rigidly structured organizations [Utterback, Abernathy, 1975]. The knowledge changes as a product passes through its life-cycle and these changes are related to changes occurring in the competitive focus of an organization [Moore, Tushman, 1982]. This implies that, while managing the organizational structure, it is necessary to keep in mind that the criteria of its appropriateness can change through time. An organization that sets out to manage knowledge needs open channels of communication, decentralization, and informal decision making, as well as flexibility in processes and procedures for this purpose. Such organizations need to set up a knowledge network. Hence, organizations with a more flexible structure will have higher rates of knowledge than other organizations.

Culture: In the last few decades, management scholars have proposed various definitions for the concept of an organizational culture [Martin, 2002; Schultz, 1995; Smircich, 1983]. In this article, organizational culture has been defined as a set of shared mental assumptions that guide interpretation and action in organizations by defining appropriate behavior for various situations [Martin, 2002; Fiol et al., 1998; Louis, 1983]. This implies organizational features that improve the conditions of knowledge sharing in knowledge networks. Knowledge culture should involve mutual trust [Zahra et al., 2007; Jennex, Olfman, 2001]. The culture of each organization develops over time to reflect the organization's identity in two dimensions: the visible and invisible [Ismail Al-Alawi et al., 2007]. The visible dimension of culture is reflected in the espoused values, philosophy, and mission of the firm while the invisible dimension lies in the unspoken set of values that guide employees' actions and perceptions in the organization [McDermott, O'Dell, 2001]. These largely tacit rules are expressed and manifested in a web of formal and informal practices and of visual, verbal, and material artifacts, which represent the most visible, tangible, and audible elements of the culture of an organization [Schein, 1993; Trice, Beyer, 1984].

Communication process: Another important factor that is influential in the implementation of knowledge networks are communication processes, which play an important role in the formation and development of internal organizations' networks [Back et al., 2005; Figallo, Rhine, 2002; Johnson, 2006]. Communication here refers to human interaction through oral conversations and the use of body language while communicating. Human interaction is greatly enhanced by the existence of social networking in the workplace [Ismail Al-Alawi et al., 2007]. This form of communication is fundamental in encouraging knowledge transfer [Smith, Rupp, 2002]. Communication processes, including knowledge forums, think tanks, knowledge workshops, brainstorming sessions, etc., form personnel's relationships and facilitate knowledge relations in organizations [Back et al., 2005]. An increase in knowledge relations in knowledge networks accelerates the flow of knowledge in organizations and thus increases the reproduction of knowledge in networks.

Knowledge Resource: Organizations are viewed as bodies of knowledge [Back et al., 2005]. The capabilities of organizations for creating and transferring knowledge have been identified as a central element of organizational advantages [Nahapiet, Ghoshal, 1998]. Knowledge embedded in the business processes of an organization and employees' skills provides the organization with capabilities to deliver products or services to customers [Maglitta, 1996; Nonaka, 1994]. Although the terms in the literature are different, the three kinds of intellectual capital proposed by Stewart [Stewart, 1997] include total knowledge resources.

- Human capital refers to the capacity to solve a problem and this is a source of creativity. Human capital is similar to the terms employee knowledge, employee competences, and professional intellect as suggested by Sveiby [Sveiby, 1997] and Quinn et al. [Quinn et al., 1996]. This is relevant to employees as know-what, know-how, know-why and help self-motivated creativity [Mayo, 1998].

- Structural capital is the organizational capability of an organization to meet the needs of the market. Organizing capability refers to the organizational structure, process, systems, patent, culture, documented experiences and knowledge, and the capability to leverage knowledge through sharing and transferring [Holsapple, Joshi, 1999]. 
- Customer capital concerns the relationship between an organization and its stakeholders, such as supplier or customer relationships, brand, and reputation. Stewart [Stewart, 1997] and Sveiby [Sveiby, 1997] called it an 'external structure'.

Managerial Processes: Another factor chosen from the review of literature was managerial processes [Askarany et al., 2007; Joshi, 2006; Lin, 2008; Palmié, 2012]. According to Hammer and Champy, management mechanisms can be defined as a series of activities involving one or more types of input and the production of outputs valuable for both the company and the customer [Hammer, Champy, 1993]. This factor includes processes such as performance management, succession management, and innovation management that form the basis of the value chain concept [Porter, 1996]. Considering that managerial processes implement major activities of knowledge management and increase the flow of knowledge in the knowledge network, they were chosen as important factors influencing the successful implementation of knowledge networks in organizations [Back et al., 2005; Kim et al., 2006; von Krogh et al., 2001; Nonaka et al., 1996].

IT Infrastructure: There are wide varieties of IT hardware and software tools that facilitate the codification, conversation, and management of knowledge. Moreover, the knowledge management process depends on the IT [Carneiro, 2000]. A major benefit of IT usage in knowledge management is speed and accuracy. The current IT networks enable tremendous opportunities for communication among people in the modern world. One of the best ways to transfer knowledge among individuals in knowledge networks is the use of virtual networks [Mahdavi, 2004]. Regarding this fact, software and hardware were selected as two important factors in the implementation of knowledge networks. Knowledge networks can be supported with IT in two ways, the first is to directly support the knowledge work process occurring in knowledge networks with so called knowledge work process services. The second possibility is network support systems from network lifecycle services [Allen, 1977; Holtshouse et al., 2013].

\section{Research Methodology}

Through tools such as online computerized search engines like Science Direct, Emerald, Taylor and Francis, Google Scholar, Springer Link, Bing, etc., the relevant literature was first reviewed by the use of primary keywords such as knowledge network, ISM and secondary keywords like knowledge sharing, knowledge management, and seven variables had been selected, then were prepared for modeling within the ISM methodology, which is used to develop a hierarchy of system variables. ISM is interpretive in that the judgment of the group decides whether and how the variables are related. The identified linkages were structured and portrayed graphically.

The ISM methodology helps one impose order and direction on the complexity of relationships among the elements of a system [Sage, 1977]. For complex problems, such as the one under consideration, a number of factors may affect the knowledge networks. However, the direct and indirect relationships between the factors describe the situation far more accurately than the individual factors taken in isolation. Therefore, ISM develops insights into the collective understandings of these relationships. Figure 1 shows the flow chart for the research methodology adopted in this paper.

The statistical population of this study included university professors of management and industry experts selected using non-probability sampling, a combination of purposive and chain methods, and the snowball method. There were two important criteria for the selection of members for brainstorming: selected members should be from academia (Professor of Management is preferred) or industry. Frst, researchers selected 12 people who were considered appropriate for the study. These people were then asked to choose other experts, and thus, seven experts were selected using the snowball method. In total, 19 experts were selected for brainstorming.

\section{Research Findings}

\section{ISM Analysis}

ISM has several steps as shown at Figure 1. From the variables identified through the literature review and the experts' opinion (see Table 2), the structural self-interaction matrix (SSIM) was developed. SSIM establishes contextual relationships among the variables by relating each of the variables with other variables, one by one, pair-wise, through rows and columns (Table 3).

To develop the initial reachability matrix, the SSIM Table is converted by transforming the information of each of its cells into the binary digits of " $0 \mathrm{~s}$ " and " $1 \mathrm{~s}$ " according to the rules presented in Table 4 . Following these rules, the initial reachability matrix for the variables is developed and is shown in Table 5. An initial reachability matrix developed from the SSIM was checked for transitivity. The transitivity of the contextual relationship is a basic assumption made in ISM. It states that if a variable $i$ is related to $j$ and $j$ is related to $k$, then $i$ is necessarily related to $k$. Thus, a final reachability matrix was obtained (Table 6).

The next step was level partitioning. Based on the suggestions of Warfield [Warfield, 1974] and Farris and Sage [Farris, Sage, 1975], the reachability and predecessor set for each variable is defined from the final reachability matrix. The reachability laid down for a particular variable consists of the variable itself and the other variables, which it may help achieve certain goals. Similarly, the antecedent set consists of the variable itself and the other variables which may assist in achieving them. After finding the reachability set and antecedent set for each variable, the intersection of these sets was derived for all the variables. The variables for which the reachability and the intersection sets are the same is presented as the top-level variable in the ISM hierarchy, which would not help achieve any other variable above their own level. After the identification of the top-level variable, it was removed from the other remaining variables. This 
Figure 1. Research Methodology Map
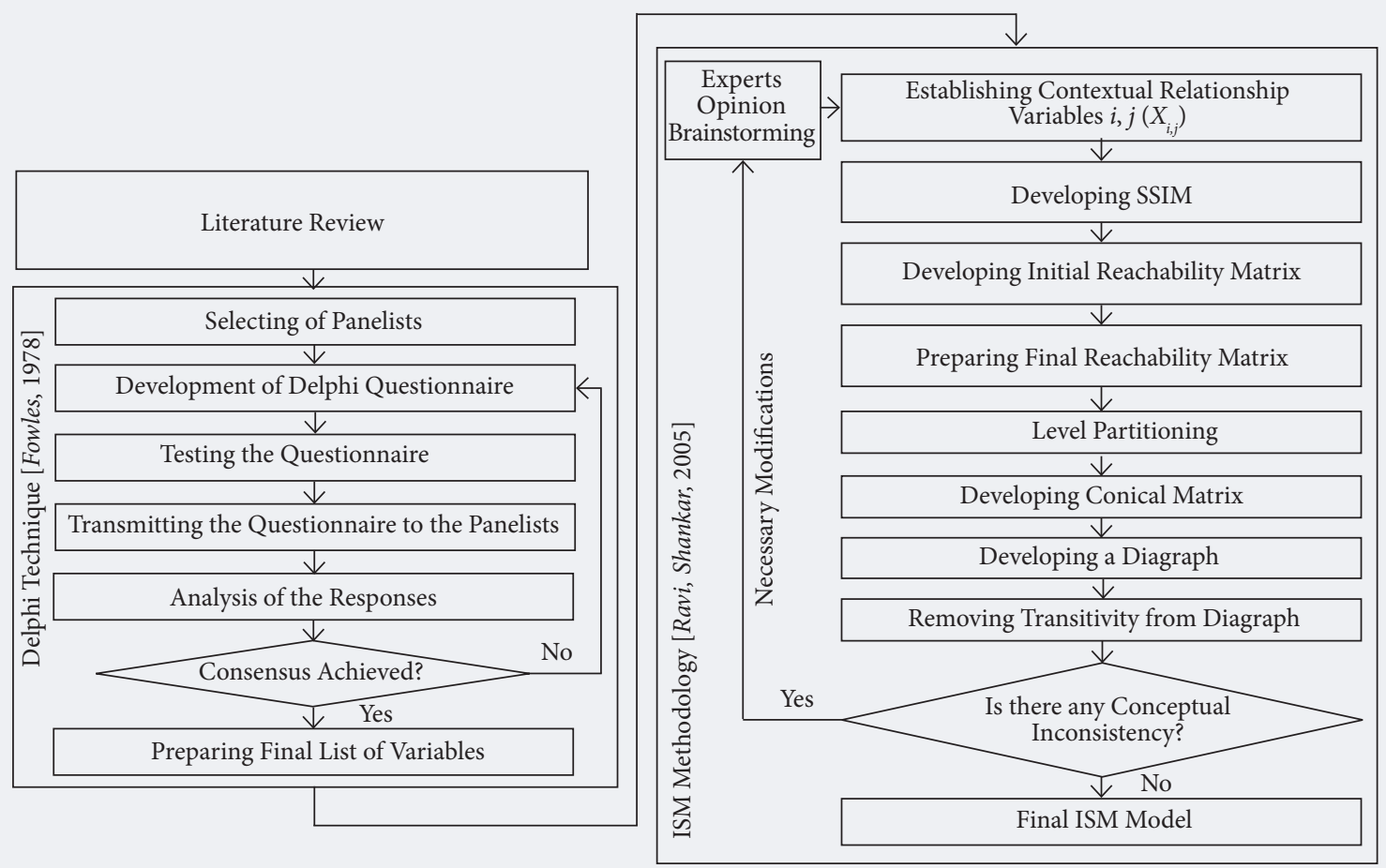

Source: composed by the authors.

iteration is continued until the levels of each variable were determined. The levels so determined help in building the diagram and the final model of the ISM. The variables along with their reachability set, antecedent set, intersection set, and the different levels, are shown in Table 7. On the basis of the levels partitions and a final reachability matrix, a conical matrix was constructed (Table 8). A directed graph or digraph was drawn and transitive links were removed. The resultant diagram was converted into an ISM model, Figure 2. The ISM model was reviewed to check for conceptual inconsistency, and necessary modifications were made.

\section{MICMAC analysis}

Building a matrice d'impacts croises-multipication applique' en classement (cross-impact matrix multiplication applied to classification) is shortly termed as a MICMAC analysis [Mudgal et al., 2010]. In the MICMAC examination, the dependence power and driver control of the variables are analyzed. Variables are arranged into four clusters as shown in Figure 3. Autonomous variables (first cluster) have weak driving power and weak relationship power. These variables can be segregated from the system.

\section{Table 3. Structural Self-Interaction Matrix}

\begin{tabular}{|c|c|c|c|c|c|c|c|c|}
\hline № & Variables & 1 & 2 & 3 & 4 & 5 & 6 & 7 \\
\hline 1 & Organizational Environmental Factors & & $\mathrm{O}$ & $\mathrm{V}$ & $\mathrm{O}$ & $\mathrm{O}$ & $\mathrm{O}$ & $\mathrm{O}$ \\
\hline 2 & Knowledge Resource & & & A & A & $\mathrm{O}$ & V & V \\
\hline 3 & Culture & & & & $\mathrm{O}$ & $\mathrm{O}$ & A & $\mathrm{X}$ \\
\hline 4 & IT Infrastructure & & & & & A & $\mathrm{O}$ & $\mathrm{V}$ \\
\hline 5 & Managerial Process & & & & & & $\mathrm{V}$ & V \\
\hline 6 & Organizational Structures & & & & & & & V \\
\hline 7 & Communication Processes & & & & & & & \\
\hline \multicolumn{9}{|c|}{$\begin{array}{l}\text { Note: The following four symbols have been used to denote the direction of the relationship between the two variables }(i \text { and } j \text { ): } \\
\text { (1) } \mathrm{V}=\text { is used for the relationship from variable } i \text { to variable } j \text { (i.e., if variable } i \text { "will help achieve" or "will help alleviate" variable } j \text { ). } \\
\text { (2) } \mathrm{A}=\text { is used for the relationship from variable } j \text { to variable } i \text { (i.e., if variable } j \text { "will be achieved by" or "will be alleviated by variable } i \text { ). } \\
\text { (3) } \mathrm{X}=\text { is used for both directions of the relationships (i.e., if variables } i \text { and } j \text { "help achieve each other"). } \\
\text { (4) } \mathrm{O}=\text { is used for no relationship between two variables (i.e., if variables } i \text { and } j \text { are not related) }\end{array}$} \\
\hline
\end{tabular}




\section{Table 4. Rules for Converting SSIM Matrix Cells into Binary IRM Variables}

\begin{tabular}{|c|c|c|}
\hline $\begin{array}{c}\text { Value of the cell } \\
(\boldsymbol{i}, \boldsymbol{j}) \text { in the SSIM } \\
\text { matrix }\end{array}$ & $\begin{array}{c}\text { Value of the cell }(\boldsymbol{i}, \boldsymbol{j}) \\
\text { in the IRM matrix }\end{array}$ & $\begin{array}{c}\text { Value of the cell } \\
(\boldsymbol{j}, \boldsymbol{i}) \text { in the IRM } \\
\text { matrix }\end{array}$ \\
\hline $\mathrm{V}$ & 1 & 0 \\
\hline $\mathrm{A}$ & 0 & 1 \\
\hline $\mathrm{X}$ & 1 & 1 \\
\hline $\mathrm{O}$ & 0 & 0 \\
\hline * Meanings of the values provided within Table 3. \\
Source: composed by the authors. \\
\hline
\end{tabular}

\section{Table 5. Initial Reachability Matrix}

\begin{tabular}{|c|l|c|c|c|c|c|c|c|}
\hline No. & \multicolumn{1}{|c|}{ Variable } & $\mathbf{1}$ & $\mathbf{2}$ & $\mathbf{3}$ & $\mathbf{4}$ & $\mathbf{5}$ & $\mathbf{6}$ & $\mathbf{7}$ \\
\hline 1 & $\begin{array}{l}\text { Organizational Environmental } \\
\text { Factors }\end{array}$ & 1 & 0 & 1 & 0 & 0 & 0 & 0 \\
\hline 2 & Knowledge Resource & 0 & 1 & 0 & 0 & 0 & 1 & 1 \\
\hline 3 & Culture & 0 & 1 & 1 & 0 & 0 & 0 & 1 \\
\hline 4 & IT Infrastructure & 0 & 1 & 0 & 1 & 0 & 0 & 1 \\
\hline 5 & Managerial Processes & 0 & 0 & 0 & 1 & 1 & 1 & 1 \\
\hline 6 & Organizational Structures & 0 & 0 & 1 & 0 & 0 & 1 & 1 \\
\hline 7 & Communication Processes & 0 & 1 & 1 & 0 & 0 & 0 & 1 \\
\hline Source: composed by the authors. & \multicolumn{7}{|c|}{} \\
\hline
\end{tabular}

The second cluster, named dependent variables, have weak driving power and strong relationship power. The third cluster, called linkage variables, has strong driving power and great dependence power. The fourth cluster, identified as independent variables, has strong driving power and weak relationship power. The final reachability matrix (Table 9) shows amount of driving power and dependence.

The MICMAC analysis (Figure 3) shows that there are no autonomous variables seen in the driver-dependence power diagram, thus indicating that all of the considered variables play an important role in the successful implementation of a knowledge network. Variables such as "knowledge resource, culture, organizational structures and communication processes" possess weak driving powers but high dependency on other variables. They are seen at the top of the ISM hierarchy (Figure 2). These variables represent a favorable outcome for the managers and practitioners. Hence, handling these variables should demand particular attention. No variables are seen as a linkage variable that has strong driving power as well as high dependence. Thus, it can be deduced that all the variables of the knowledge network identified are stable. Finally, the driver - dependence power diagram indicates that independent variables such as "Organizational environmental factors, Managerial processes, IT infrastructure" are at the bottom of the ISM hierarchy, having strong driving power and weak dependence (see Figure 3). They may be treated as "important variables" for the successful implementation of a knowledge network. Thus, senior managers should place a high priority on these variables.

\section{Table 6. Final Reachability Matrix}

\begin{tabular}{|c|l|c|c|c|c|c|c|c|c|}
\hline No. & \multicolumn{1}{|c|}{ Variable } & $\mathbf{1}$ & $\mathbf{2}$ & $\mathbf{3}$ & $\mathbf{4}$ & $\mathbf{5}$ & $\mathbf{6}$ & $\mathbf{7}$ & Driving power \\
\hline 1 & Organizational Environmental Factors & 1 & 1 & 1 & 0 & 0 & 1 & 1 & $\mathbf{5}$ \\
\hline 2 & Knowledge Resource & 0 & 1 & 1 & 0 & 0 & 1 & 1 & $\mathbf{4}$ \\
\hline 3 & Culture & 0 & 1 & 1 & 0 & 0 & 1 & 1 & $\mathbf{4}$ \\
\hline 4 & IT Infrastructure & 0 & 1 & 1 & 1 & 0 & 1 & 1 & $\mathbf{5}$ \\
\hline 5 & Managerial Processes & 0 & 1 & 1 & 1 & 1 & 1 & 1 & 7 \\
\hline 6 & Organizational Structures & 0 & 1 & 1 & 0 & 0 & 1 & 1 & $\mathbf{4}$ \\
\hline 7 & Communication Processes & 0 & 1 & 1 & 0 & 0 & 1 & 1 & $\mathbf{4}$ \\
\hline \multicolumn{2}{|r|}{ Dependence power } & $\mathbf{1}$ & $\mathbf{8}$ & $\mathbf{8}$ & $\mathbf{3}$ & $\mathbf{1}$ & $\mathbf{8}$ & $\mathbf{8}$ & \\
\hline
\end{tabular}

\section{Table 7. Variable Level Partitioning}

\begin{tabular}{|c|c|c|c|c|}
\hline No. & Reachability set & Antecedent set & Intersection set & Level \\
\hline \multicolumn{5}{|c|}{ Iteration I } \\
\hline 1 & $1,2,3,7,8$ & 1 & 1 & \\
\hline 2 & $2,3,7,8$ & $1,2,3,4,5,6,7,8$ & $2,3,7,8$ & I \\
\hline 3 & $2,3,7,8$ & $1,2,3,4,5,6,7,8$ & $2,3,7,8$ & I \\
\hline 4 & $2,3,4,5,7,8$ & $4,5,6$ & 4,5 & \\
\hline 5 & $2,3,4,5,6,7,8$ & 6 & 6 & \\
\hline 6 & $2,3,7,8$ & $1,2,3,4,5,6,7,8$ & $2,3,7,8$ & I \\
\hline 7 & $2,3,7,8$ & $1,2,3,4,5,6,7,8$ & $2,3,7,8$ & I \\
\hline \multicolumn{5}{|c|}{ Iteration II } \\
\hline 1 & 1 & 1 & 1 & II \\
\hline 4 & 4 & 4,5 & 4 & II \\
\hline 5 & 4,5 & 5 & 5 & \\
\hline \multicolumn{5}{|c|}{ Iteration III } \\
\hline 5 & 5 & 5 & 5 & III \\
\hline $\begin{array}{l}\text { Note: table } \\
\text { Source: co }\end{array}$ & $\begin{array}{l}\text { numbers of studied v } \\
\text { authors. }\end{array}$ & & & \\
\hline
\end{tabular}




\section{Table 8. Conical Matrix}

\begin{tabular}{|c|c|c|}
\hline Level & No. & Construct \\
\hline I & $2,3,6,7$ & $\begin{array}{c}\text { Knowledge Resource, Culture, } \\
\text { Organizational Structures, } \\
\text { Communication Processes }\end{array}$ \\
\hline II & 1,4 & $\begin{array}{c}\text { Organizational Environmental } \\
\text { Factors, IT Infrastructure }\end{array}$ \\
\hline III & 5 & Managerial Process \\
\hline Source: composed by the authors. \\
\hline
\end{tabular}

Table 9. Driving Power and Dependency

\begin{tabular}{|c|l|c|c|}
\hline No. & \multicolumn{1}{|c|}{ Variable } & $\begin{array}{c}\text { Driving } \\
\text { power }\end{array}$ & Dependency \\
\hline 1 & $\begin{array}{l}\text { Organizational } \\
\text { Environmental Factors }\end{array}$ & 5 & 1 \\
\hline 2 & Knowledge Resource & 4 & 8 \\
\hline 3 & Culture & 4 & 8 \\
\hline 4 & IT Infrastructure & 5 & 2 \\
\hline 5 & Managerial Processes & 7 & 1 \\
\hline 6 & Organizational Structures & 4 & 8 \\
\hline 7 & Communication Processes & 4 & 8 \\
\hline Source: composed by the authors. & & \\
\hline
\end{tabular}

\section{Discussion and Conclusion}

Through related pieces of literature, seven major variables have been identified that define the performance of networking aimed at knowledge generation and transfer. The ISM methodology has been used in finding contextual relationships among various variables and building a respective model. "Knowledge Resource", "Culture", "Organizational Structures" and "Communication Processes" have been identified as top-level variables and "Managerial processes" as the most important bottom-level variable. The main objective of this research was to analyze the interaction among the various variables of a knowledge network that determine the successful implementation of a knowledge network and to develop a hierarchy of elements that would help in understanding the relevant processes. Therefore, an ISM-based model on knowledge network variables has been developed. These elements assume importance because in certain conditions they hinder the knowledge network implementation program and pose considerable challenges for the users of knowledge networks. Some of the major variables have been discussed here and placed into an ISM model to analyze the interaction between these elements. The present research emphasizes that there is a need to prepare these variables for the successful implementation of a knowledge network to better manage knowledge and improve knowledge relationships and the applications of knowledge to gain organizational goals. Special attention should be paid to make more knowledge relations between experts of organization and coordination among processes such as managerial processes, communication processes and organizational structures.

A MICMAC analysis was also carried out. The driving power and dependence control diagram helps to categorize the various variables for an effective knowledge network. Four variables having high dependence and relatively low driving power were identified as lying between the clusters of dependent variables and clusters of linkage variables (i.e., knowledge resource, culture, organizational structures, and communication processes). The rest of the three variables have been identified as driver variables (such as organizational environmental factors, managerial processes, and IT infrastructure). The research showed that this group of variables is of strategic importance for the successful implementation of a knowledge network and require maximum attention. No variables were identified as autonomous. It should be noted that none of the variables can be considered linkage variables because there is no certainty that any action made upon these variables will have an effect on the others or feedback upon themselves. The driver-dependence diagram (Figure 3) gives some valuable insights into the relative importance and the

\section{Figure 2. Final Model}

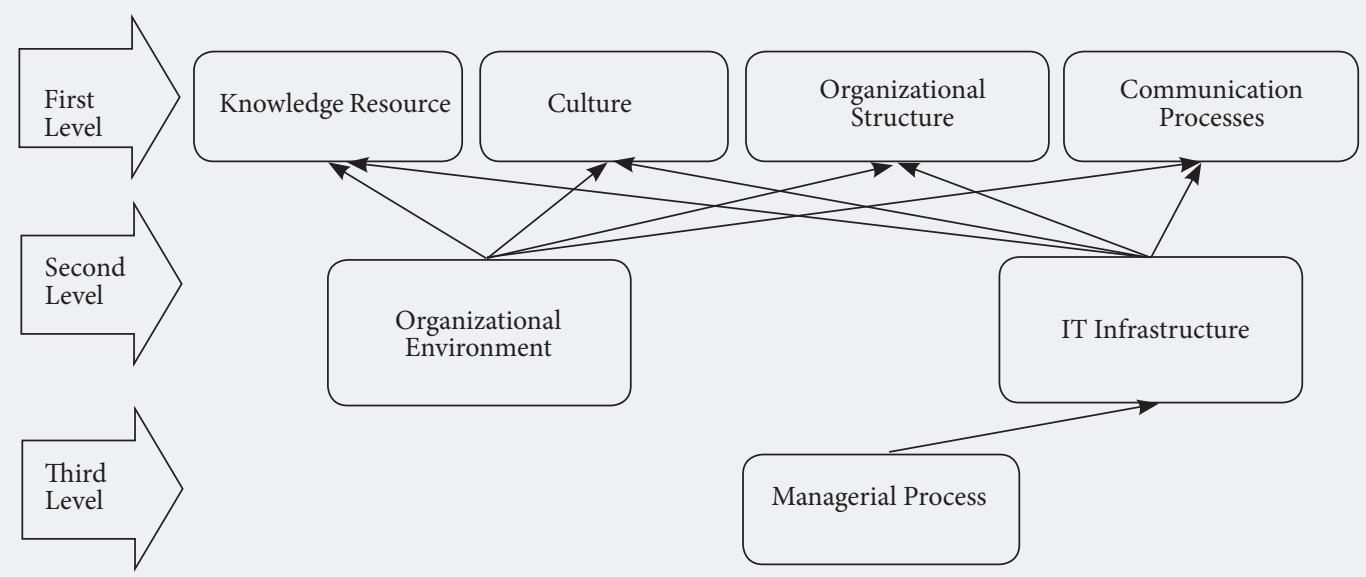

Source: composed by the authors. 


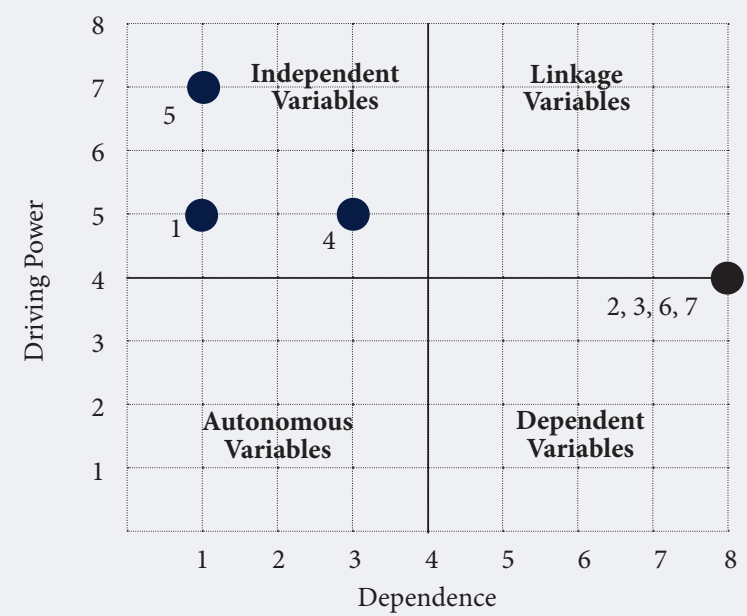

Source: composed by the authors.

interdependencies among the variables. This can provide better insights for the executive managers so that they can proactively deal with these important variables.

The main contribution of this research is that an attempt has been made to analyze the variables for the successful implementation of a knowledge network and is brought to one platform. The present ISM-based model will help one understand the crux of the relationships and obtain feasible insights on possible obstacles to networking. From the ISM model, it was observed that "managerial processes" is at the bottom level of the hierarchy implying higher driving power. Therefore, managers should focus on developing managerial processes and mechanisms in order to create specific channels to monitor and control personnel duties and motivate them to share their knowledge and to coordinate with one another, thus ensuring healthy relationships between different personnel and departments.

The utility of the proposed ISM methodology lies in analyzing and ranking the knowledge network variables by driving/dependence power, imposing order and direction on the complexity of the relationships among these variables, which could facilitate better networking. Those variables maintaining higher driving power in the ISM require being dealt with care on a priority basis because they influence the culture, knowledge resources, organizational structures, and communication processes.

Finally, it would be useful to suggest directions for future research in this area. The knowledge network implementation issues may vary from country to country, so may the work culture of the organization and geographic location within the country. The present model must be statistically tested and verified using different approaches, one of which could be the "Structural Equation Modeling" (SEM) approach, also referred to as the linear structural relationship approach. Statistical software like Lisrel 8.7 and Amos 23.0.0 can be used in the future to build a correlation matrix, confirmatory factor analysis (CFA), and diagram to validate the relationships. Comparing ISM and SEM, SEM has the capability of statistically testing an already developed theoretical model whereas ISM, on the other hand, can develop an initial model through managerial techniques such as brainstorming, nominal group techniques, and idea engineering. In this way, ISM serves as a supportive analytical tool in this situation. However, it may be suggested that, due to the complimentary nature of both of these techniques, future research may be directed to first developing an initial model using ISM and then testing it using SEM. The ISM also helps in classifying variables into the dependent, independent, autonomous, and linkage categories. Senior managers may use their resources over the identified factors. Thus, an optimization of resources may be accomplished. Furthermore, the systemic framework proposed in this study has broad applications and can be used to improve the performance, administrative abilities, and the effectiveness of an organization.

\section{References}

Alavi M., Leidner D. (1999) Knowledge management systems: Emerging views and practices from the field. Paper presented at the 32nd Hawaii International Conference on System Sciences, IEEE Computer Society. Available at: http://citeseerx.ist.psu.edu/viewdoc/download?doi=10.1.1.95.9893\&rep=rep1\&type=pdf, accessed 10.11.2016.

Alba R. (1982) Taking Stock of Network Analysis: A Decade's Results. Research in the Sociology of Organizations (ed. S. Bacharach), Greenwich, CN: JAI Press, pp. 38-74.

Alkhuraiji A., Liu S., Oderanti F.O., Annansingh F., Pan J. (2014) Knowledge network modelling to support decisionmaking for strategic intervention in IT project oriented change management. Journal of Decision Systems, vol. 23, no 3, pp. 285-302.

Alkhuraiji A., Liu S., Oderanti F.O., Megicks P. (2016) New structured knowledge network for strategic decisionmaking in innovative and implementable projects. Journal of Business Research, vol. 69, no 5, pp. 1534-1538. 
Allen T. (1977) Managing the flow of technology transfer and the dissemination of technological information within R\&D organization, Cambridge; London: MIT Press.

Argote L. (2012) Organizational Learning: Creating, Retaining and Transferring Knowledge, Heidelberg; New York; Dordrecht; London: Springer.

Askarany D., Smith M., Yazdifar H. (2007) Attributes of innovation and the implementation of managerial tools: An activity-based management technique. International Journal of Business and Systems Research, vol. 1, no 1, pp. 98-114.

Back A., von Krogh G., Seufert A. (2005) Putting knowledge networks into action: Methodology, development, maintenance, Heidelberg; New York; Dordrecht; London: Springer.

Badaracco J. (1991) The knowledge link: How firms compete through strategic alliances, Boston, MA: Harvard Business School Press.

Barna Z. (2003) Knowledge management: A critical e-business strategic factor, San Diego, CA: San Diego State University (MSc. Thesis).

Benson V., Morgan S., Tennakoon H. (2012) A framework for knowledge management in higher education using social networking. International Journal of Knowledge Society Research, vol. 3, no 2, pp. 44-54.

Carneiro A. (2000) How does knowledge management influence innovation and competitiveness? Journal of Knowledge Management, vol. 4, no 2, pp. 87-98.

Cross R., Baird L. (2000) Technology is not enough: Improving performance by building organizational memory. Sloan Management Review, vol. 41, pp. 41-54.

Davenport T., Delong D., Beers M. (1998) Successful knowledge management projects. Sloan Management Review, vol. 39, pp. 43-57.

Diabat A., Govidan K. (2011) An analysis of the drivers affecting the implementation of green supply chain management. Resources, Conservation and Recycling, vol. 55, no 6, pp. 659-667.

Duncan R.B. (1972) Characteristics of organizational environments and perceived environmental uncertainty. Administrative Science Quarterly, vol. 17, no 3, pp. 313-327.

Easton G. (1992) Industrial networks: A review. Industrial networks - A new view of reality (eds. B. Axelsson, G. Easton), London: Routledge, pp. 1-28.

Enkel E., Back A., von Krogh G. (2007) The concept of knowledge networks for growth. Knowledge networks for business growth (eds. G. von Krogh, A. Back, E. Enkel), Heidelberg; New York; Dordrecht; London: Springer, pp. 1-31.

Farris D., Sage A. (1975) On the use of interpretive structural modeling for worth assessment. Computers and Electrical Engineering, vol. 2, no 2-3, pp. 149-174.

Fayol H. (1917) Administration industrielle et générale; prévoyance, organisation, commandement, coordination, controle, Paris: H. Dunod \& E. Pinat.

Figallo C., Rhine N. (2002) Building the knowledge management network: Best practices, tools, and techniques for putting conversation to work, New York: Wiley.

Fiol M., Hatch M., Golden-Biddle K. (1998) Organizational culture and identity: What's the difference anyway? Identity in Organizations (eds. D. Whetten, P. Godfrey), Thousand Oaks, CA: Sage, pp. 56-59.

Fowles J. (1978) Handbook of futures research, Westport, CT: Greenwood Publishing.

Ginsberg M., Kambil A. (1999) Annotate: A web-based knowledge management support system for document collections. Paper presented at the 32nd Hawaii International Conference on System Sciences, IEEE Computer Society. Available at: https://www.computer.org/csdl/proceedings/hicss/1999/0001/01/00011073.pdf, accessed 19.11.2016.

Gupta S., Polonsky M. (2014) Inter-firm learning and knowledge-sharing in multinational networks: An outsourced organization's perspective. Journal of Business Research, vol. 67, no 4, pp. 615-622.

Hammer M., Champy J. (1993) Reengineering the Corporation, New York: Harper Business.

Harary F., Norman R., Cartwright Z. (1956) Structural models: An introduction to the theory of directed graphs, New York: Wiley.

Hawthorne R.W., Sage A. (1975) On applications of interpretive structural modeling to higher education program planning. Socio-Economic Planning Sciences, vol. 9, no 3, pp. 31-43.

Hildreth P., Kimble C. (2004) Knowledge networks: Innovation through communities of practice, Hershey, PA: Idea Group Publishing.

Holsapple C., Joshi K. (1999) Description and analysis of existing knowledge management frameworks. Paper presented at the 32nd Hawaii International Conference on System Sciences, IEEE Computer Society. Available at: http://citeseerx.ist.psu.edu/viewdoc/download?doi=10.1.1.99.3050\&rep=rep1\&type=pdf, accessed 19.11.2016.

Holtshouse D., Borghoff U.M., Pareschi R. (2013) Information technology for knowledge management, Heidelberg; New York; Dordrecht; London: Springer.

Hung W.C. (2006) Researching the researcher: A social network analysis of the multidisciplinary knowledge creation process, Waterloo, ON (Canada): University of Waterloo (MSc. Thesis).

Ismail Al-Alawi A., Yousif Al-Marzooqi N., Fraidoon Mohammed Y. (2007) Organizational culture and knowledge sharing: Critical success factors. Journal of Knowledge Management, vol. 11, no 2, pp. 22-42.

Jayrama A., Ayvari A. (2005) Can the knowledge creation process be managed? A case study of an artist training project. International Journal of Arts Management, vol. 7, no 2, pp. 4-14.

Jennex M., Olfman L. (2001) Development recommendations for knowledge management organizational memory systems. Contemporary Trends in Systems Development (eds. M.K. Sein, B.E. Munkvold, T.U. Orvik, W. Wojtkowski, W. G.Wojtkowski, J. Zupančič, S. Wrycza), Heidelberg; New York; Dordrecht; London: Springer, pp. 209-222.

Jennex M., Olfman L. (2004) Assessing knowledge management success/effectiveness models. Paper presented at the 37th IEEE Annual Hawaii International Conference on System Sciences. Available at: http://citeseerx.ist.psu.edu/ viewdoc/download?doi=10.1.1.123.6335\&rep=rep1\&type=pdf, accessed 15.11.2016.

Jharkharia S., Shankar R. (2005) IT enablement of supply chains: Understanding the barriers. Journal of Enterprise Information Management, vol. 18, no 1, pp. 11-27.

Johnson J. (2006) A sociometric analysis of influence relationships within a community of practice. Studies in Communication Sciences, vol. 6, pp. 63-92.

Joshi A. (2006) The influence of organizational demography on the external networking behavior of teams. Academy of Management Journal, vol. 31, no 3, pp. 583-595.

Kant R., Singh M. (2008) Knowledge management implementation: Modeling the barriers. Journal of Information and Knowledge Management, vol. 7, no 4, pp. 291-305.

Kanungo S. (2009) Two organizational case studies of IT-enabled value. Systems Research and Behavioral Science, vol. 26, no 6, pp. 689-707. 
Kim T., Oh H., Swaminathan A. (2006) Framing interorganizational network change: A network inertia perspective. Academy of Management Review, vol. 31, no 3, pp. 704-720.

Klimasauskiene R. (2003) Enhancing science-based innovations through knowledge mobility between higher education and educational practice. Paper presented at the European Conference on Educational Research, University of Hamburg, 17-20 September 2003. Available at: http://www.leeds.ac.uk/educol/documents/00003415.htm, accessed 23.12.2017.

Kogut B. (2000) The network as knowledge: Generative rules and emergence of structure. Strategic Management Journal, vol. 21, no 3, pp. 405-425.

Leonard D. (2006) Innovation as a knowledge generation and transfer process communication of innovations. Communication of Innovations: A Journey with Ev Rogers, Thousand Oaks, CA: Sage, pp. 15-28.

Lewis-Pryde J., Evans R.D. (2016) A social networking strategy for improving knowledge management and communication in the travel industry. Paper presented at the 3rd Multidisciplinary International Social Networks Conference on Social Informatics 2016, Data Science 2016. Available at: https://dl.acm.org/citation.cfm?id=2955143, accessed 23.12.2017.

Lin W. (2008) The exploration factors of affecting knowledge sharing - The case of Taiwan's high-tech industry. Expert Systems with Applications, vol. 35, pp. 661-676. DOI: 10.1016/j.eswa.2007.07.038.

Lincoln J. (1982) Intra- (and inter-) organizational networks. Research in the Sociology of Organizations (ed. S.B. Bacharach), Greenwich, CN: JAI Press, pp. 1-38.

Louis M.R. (1983) Organizations as culture-bearing milieu. Organizational Symbolism (eds. L. Pondy, P.J. Frost, G. Morgan, T. Dandridge), Greenwich, CN: JAI Press, pp. 39-54.

Luthra S., Kumar V., Kumar S., Haleem A. (2011) Barriers to implement green supply chain management in automobile industry using interpretive structural modeling technique - An Indian perspective. Journal of Industrial Engineering and Management, vol. 4, no 2, pp. 231-257.

Maglitta J. (1996) Know-How, Inc. Computerworld, vol. 30, no 1, pp. 75-77.

Mahdavi A. (2004) Border-crossing knowledge networking among multinational firms: The case of R\&D facilities, Cambridge, MA: Massachusetts Institute of Technology (PhD Thesis).

Mandal A., Deshmukh S.G. (1994) Vendor selection using interpretive structural modeling (ISM). International Journal of Operation \& Production Management, vol. 14, no 6, pp. 52-59.

Martin J. (2002) Breaking up the mono-method monopoly in organizational analysis. The theory and philosophy of organizations: Critical issues and new perspectives (eds. J. Hassard, D. Pym), London; New York: Routledge, pp. 30-43.

Matkovic P., Tumbas P. (2010) A comparative overview of the evolution of software development models. International Journal of Industrial Engineering and Management, vol. 1, no 4, pp. 163-172.

Mayo A. (1998) Memory bankers. People Management, vol. 2, no 4, pp. 34-38.

McDermott R., O’Dell C. (2001) Overcoming cultural barriers to sharing knowledge. Journal of Knowledge Management Review, vol. 5, no 1, pp. 76-85.

Miles G., Miles R., Perrone V., Edvinson L. (1998) Some conceptual and research barriers to the utilization of knowledge. California Management Review, vol. 40, no 3, pp. 281-288.

Miles R., Snow C. (1986) Network organizations: New concepts for new forms. California Management Review, vol. 34 , no 2, pp. 53-72.

Miller D., Droge C. (1986) Psychological and traditional determinants of structure. Administrative Science Quarterly, vol. 31, no 4, pp. 539-560.

Mitchell J. (1969) The concept and use of social networks. Social Networks in Urban Situations: Analyses of Personal Relationships in Central African Towns (ed. J. C. Mitchell), Manchester: Manchester University Press, pp. 1-50.

Moore W., Tushman M. (1982) Managing innovation over the life cycle. Reading in the Management of Innovation (eds. W. Moore, M. Tushman), Marshfield, MA: Pitman Publishing, pp. 131-150.

Mudgal R., Shankar R., Talib P., Raj T. (2009) Greening the supply chain practices: An Indian perspective of enablers' relationship. International Journal of Advanced Operations Management, vol. 1, no 2-3, pp. 151-176.

Mudgal R., Shankar R., Talib P., Raj T. (2010) Modeling the barriers of green supply chain practices: An Indian perspective. International Journal of Logistics Systems and Management, vol. 7, no 1, pp. 81-107.

Nahapiet J., Ghoshal S. (1998) Social capital, intellectual capital, and organizational advantage. Academy of Management Review, vol. 23, no 2, pp. 242-266.

Nonaka I. (1994) A dynamic theory of organizational knowledge creation. Organization Science, vol. 5, no 1, pp. 14-37.

Nonaka I., Reinmoeller P., Senoo D. (1998) The art of knowledge: Systems to capitalize on market knowledge. European Management Journal, vol. 16, no 6, pp. 673-684.

Nonaka I., Takeuchi H., Umemoto K. (1996) A theory of organizational knowledge creation. International Journal of Technology Management, vol. 11, no 7-8, pp. 833-845.

Özsomer A., Calantone R.J., di Bonetto A. (1997) What makes firms more innovative? A look at organizational and environmental factors. Journal of Business \& Industrial Marketing, vol. 12, no 6, pp. 400-416.

Palmie M.F. (2012) Organizational architecture and the realization of competitive advantages from multinationality, St. Gallen: University of St. Gallen (PhD Thesis).

Parker A., Cross R., Walsh D. (2001) Improving collaboration with social network analysis. Knowledge Management Review, vol. 4, no 2, pp. 24-28.

Patil N.Y., Warkhedkar R.M. (2016) Knowledge management implementation in Indian automobile ancillary industries: An interpretive structural model for productivity. Journal of Modelling in Management, vol. 11, no 3, pp. 802-810.

Plum O., Hassink R. (2011) Comparing knowledge networking in different knowledge bases in Germany. Papers in Regional Science, vol. 90, no 2, pp. 355-371.

Porter M. (1996) What is strategy? Harvard Business Review, vol. 74, no 6 (November-December), pp. 61-78.

Quinn J., Anderson P., Finkelstein S. (1996) Managing Professional Intellect: Making the Most of the Best. Harvard Business Review, vol. 74, no 6 (November-December), pp. 71-80.

Raiden A., Dainty A., Neale R. (2004) Current barriers and possible solutions to effective project team formation and deployment within a large construction organization. International Journal of Project Management, vol. 22, no 4, pp. 309-316.

Ravi V., Shankar R. (2005) Analysis of interactions among the barriers of reverse logistics. Technological Forecasting and Social Change, vol. 72, no 8, pp. 1011-1029.

Rice K. (1963) The Enterprise and Its Environment, London: Tavistock. 
Ring P. (1997) Processes facilitating reliance on trust in interorganizational networks. The formation of interorganizational networks, Oxford: Oxford University Press.

Sage A. (1977) Interpretive structural modeling: Methodology for large scale systems, New York: McGraw-Hill.

Sage A., Rouse W. (1999) Information systems frontiers in knowledge management. Information Systems Frontiers, vol. 1, no 3, pp. 205-219.

Sarkis J., Hasan M., Shankar R. (2007) Evaluating environmentally conscious manufacturing barriers with interpretive structural modeling. Available at: http://ssrn.com/abstract=956954, accessed 12.02.2017.

Saxena J., Vrat P. (1992) Scenario building: A critical study of energy conservation in the Indian cement industry. Technological Forecasting and Social Change, vol. 41, no 2, pp. 121-146.

Schein E.H. (1993) On dialogue, culture, and organizational learning. Organizational Dynamics, vol. 22, no 2, pp. $40-51$.

Schneckenberg D. (2015) Open innovation and knowledge networking in a multinational corporation. Journal of Business Strategy, vol. 36, no 1, pp. 14-24.

Schultz M. (1995) On studying organizational cultures: Diagnosis and understanding, Berlin: Walter de Gruyter.

Seufert A., von Krogh G., Bach A. (1999) Towards knowledge networking. Journal of Knowledge Management, vol. 3, no 3, pp. 180-190.

Sharma B., Singh M. (2013) Modeling Individual/Group Knowledge Sharing Barriers in Indian Engineering Industry - An Integrated ISM, AHP and Similarity Coefficient Approach. International Journal of Management Science and Engineering Management, vol. 8, no 3, pp. 179-198.

Sharma H., Gupta A. (1995) The objectives of waste management in India: A futures inquiry. Technological Forecasting and Social Change, vol. 48, no 3, pp. 285-309.

Singh M., Shankar R., Narain R., Agarwal A. (2003) An interpretive structural modeling of knowledge management in engineering industries. Journal of Advances in Management Research, vol. 1, no 1, pp. 28-40.

Smircich L. (1983) Organizations as shared meanings. Organizational Symbolism (eds. L. Pondy, P.J. Frost, G. Morgan, T. Dandridge), Greenwich, CN: JAI Press, pp. 55-56.

Smith A., Rupp W. (2002) Communication and loyalty among knowledge workers: A resource of the firm theory view. Journal of Knowledge Management, vol. 6, no 3, pp. 250-261.

Stewart T. (1997) Intellectual Capital: The New Wealth of Organizations, New York: Bantam Books.

Sushil (2005) Interpretive matrix: A tool to aid interpretation of management and social research. Global Journal of Flexible Systems Management, vol. 6, no 2, pp. 27-30.

Sveiby K. (1997) The new organizational wealth: Managing and measuring knowledge based assets, San Francisco, CA: Berrett-Koehler.

Swan J., Newell S., Scarbrough H., Hislop D. (1999) Knowledge management and innovation: Networks and networking. Journal of Knowledge Management, vol. 3, pp. 262-275.

Taghizadeh H., Shokri A. (2015) Relationship among the dimensions of knowledge management from the viewpoint of social capital based on interpretive structural modelling (a case study). Journal of Information and Knowledge Management, vol. 14, no 3. Available at: http://www.worldscientific.com/doi/abs/10.1142/S0219649215500240, accessed 29.11.2017.

Tavallaee R., Bamdad Soofi J., Sadaghiyan J.S., Salehifar M. (2012) Developing a model of knowledge networks in organizations-case study: Petroleum industry of I.R. Iran. International Journal of Social Science and Humanity, vol. 2, no 5, pp. 375-379.

Tichy N., Tushman M., Fombrun C. (1979) Social networks analysis for organizations. Academy of Management Review, vol. 4, no 4, pp. 507-519.

Trice H.M., Beyer J. (1984) Studying organizational cultures through rites and ceremonials. Academy of Management Review, vol. 9, no 4, pp. 653-669.

Utterback J.M., Abernathy W.J. (1975) A dynamic model of process and product innovation. Omega, vol. 3, no 6, pp. 639-656.

von Krogh G., Nonaka I., Aben M. (2001) Making the most of your company's knowledge: A strategic framework. Long Range Planning, vol. 34, pp. 421-439.

Warfield J. (1974) Developing interconnected matrices in structural modeling. IEEE Transcript on Systems, Men and Cybernetics, vol. 4, pp. 51-81.

Wejnert B. (2002) Integrating models of diffusion of innovations: A conceptual framework. Annual Review of Sociology, vol. 28, pp. 297-326.

Wood R., Hamel G. (2002) The world bank's innovation market. Harvard Business Review, vol. 80, no 11, pp. $104-111$.

Yang C., Chen L.-C. (2009) Can organizational knowledge capabilities affect knowledge sharing behavior? Journal of Information Science, vol. 33, no 1, pp. 95-109.

Yu S., Kim Y., Kim M. (2004) Linking organizational knowledge management drivers to knowledge management performance: An exploratory study. Paper presented at the 37th IEEE Annual Hawaii International Conference on System Sciences. Available at: http://citeseerx.ist.psu.edu/viewdoc/download?doi=10.1.1.98.2111\&rep=rep1\&typ $\mathrm{e}=$ pdf, accessed 15.02.2017.

Zahra S., Neubaum D., Larraneta B. (2007) Knowledge sharing and technological capabilities: The moderating role of family involvement. Journal of Business Research, vol. 60, no 10, pp. 1070-1079.

Zhou K.Z., Brown J.R., Dev C.S. (2009) Market orientation, competitive advantage, and performance: A demandbased perspective. Journal of Business Research, vol. 62, no 11, pp. 1063-1070. 